\title{
THE USE OF HISTORY IN DRACULA TOURISM IN ROMANIA
}

\author{
Tuomas Hovi
}

\begin{abstract}
Dracula tourism in Romania combines fiction with history. It is centred on either the fictional Western vampire Count Dracula or the historical Dracula, the fifteenth-century Romanian ruler Vlad the Impaler. These two characters are also often conflated, or sometimes even forged together, into one Dracula figure in Dracula tourism. Besides the history concerning the ruler, Vlad the Impaler, through Dracula tourism the guides and travel agencies also tend to offer much more history and tradition of Romania in their tours. In this article I will examine what kind of history is told and what is left out. I am especially interested in the history and tradition (as it is manipulated) that is not connected to Vlad or Dracula. I look at the types and eras of history used and emphasised in Dracula tourism in Romania, and the reasons for the choices. I am also interested in the idea of how the seemingly superficial and fictitious Dracula tourism can be used as a gateway into Romanian history and culture.
\end{abstract}

Keywords: Dracula tourism, local heritage, Romania, the use of history, tour narrations, tradition

Dracula tourism in Romania is an interesting combination of history, tradition and fiction. In Dracula tourism tourists visit locations connected to the historical Dracula, Vlad the Impaler, the ones described in Bram Stoker's novel Dracula, and some other locations in Romania that the different tourist agencies want to show to the tourists. There are many foreign and domestic tourist agencies that offer different kinds of Dracula-themed tours around Romania. Although the reaction from the Romanian government towards Dracula tourism has been ambivalent or even hostile towards the fictional side of tourism, the official website of Romanian tourism does have information about both Vlad the Impaler and the fictitious Count Dracula. ${ }^{1}$ There is, however, no section about Dracula tourism on the main page or even on the page for the main attractions in Romania. There are some pieces of information about Dracula that can be found under the pages about specific locations, but the information there is fragmental. The information about Dracula tourism is found on a page titled "Special interest", so although there is information about Dracula on the official website of Romanian tourism, it is not considered a main attraction in 
Romania by the Romanian National Tourist Office. ${ }^{2}$ There are several tourist agencies that concentrate on Dracula tourism, but they are private companies and are not affiliated with the official tourist agency of Romania. This makes the research about the connection between the fictional Dracula and Romanian history, heritage and culture, even more interesting. In this article, I explore how this somewhat controversial history culture has been developed, negotiated and represented by various agents in Romania. Although there are similar types of tourism in which historical and mythical figures have been used, I find Dracula tourism quite unique because unlike many other cases it combines a certain historical figure with a fictional character that comes completely from outside of the history and culture of the original historical figure. ${ }^{3}$

In this article I will examine what kinds of history and tradition are used and told in Dracula tourism in Romania, and which eras of history are highlighted and why. I am also interested in the negotiations between fiction, tradition and history, and how seemingly superficial and fictitious Dracula tourism can be used as a gateway into Romanian history and culture. History, and especially the use of history, is an important element in tourism. Many tourists want to find out about the history of the country they are visiting. Similarly, many local actors are eager to present their destination in a certain way and give as favourable a history or story of the locations visited as possible. History is definitely never objective; nor is the use of history in tourism. What I mean by history is the shared and widely acknowledged interpretations of the past, within given groups. These interpretations may also differ within the community and between academia and laymen. The main point is to understand that history is not the same as the past, but consists of interpretations of the past. In tourism the use of history is always a subjective decision. What eras of history are highlighted in different tourist sites and what are left out? These decisions are made by different actors that include national tourist boards, ministries of tourism, travel agencies (both foreign and domestic), the owners of locations and various tour guides. This is also the case with Dracula tourism in Romania.

What I mean by fiction in this case is everything that is connected with the fictitious vampire Count Dracula and with the image of Romania and Transylvania in popular culture in general. Although fiction can be described as something feigned or invented by imagination and specifically as an invented story, the line between history and fiction is not always very clear. Therefore it would be difficult and maybe even pointless for me as a researcher to differentiate between fiction, history and tradition used in Dracula tourism in Romania. For example, the history of Vlad the Impaler, which is used in the tour-guide narrations, is partly based on the legend tradition about Vlad, which, although to an extent based on historical events, is also more or less fiction. In this case, 
what I mean by fiction is what the tour guides themselves call fiction. So the definition and distinction between fiction, tradition and history is based on the tour guide narrations and the websites of various travel agencies ${ }^{4}$ and not on my own interpretations. Hopefully, my article will contribute to the research fields of tourism, history and folklore, and especially to the use of history and tradition in tourism. Although there are many similar cases in which the local tourism industry has to negotiate between outside expectations and local cultural values, some aspects of Dracula tourism are unique in my opinion. Because Dracula tourism combines tradition, history, culture and fiction in an interesting whole, I find it an intriguing subject for cultural research.

I have carried out fieldwork in Romania and participated in three Dracula tours organised by two different Romanian travel companies. Two of these tours were in 2010 with the Company of Mysterious Journeys, and the third was in 2011 with the company Transylvania Live. ${ }^{5}$ I selected these two travel companies because they are Romanian, because they have both been active since the early 1990s and because they both organise various kinds of Dracula tours as well as other tours that are not linked with Dracula. These tour operators are not the only ones in Romania, but they are two of the oldest, most popular and recognised ones in Romania. There are dozens of Romanian tour operators that offer some kind of Dracula tourism, but many of their tours are copied from the main tourist agencies that offer Dracula tourism.

During my fieldwork I conducted several interviews with tour guides and other tourists during and after the tours. In addition, I undertook participant observation and kept a field diary. These tours and my fieldwork within them form the basis for this article. I have also used the websites of the aforementioned travel agencies as references.

\section{DEFINING DRACULA TOURISM}

Dracula tourism is a kind of tourism in which tourists visit sites and places that are associated with both the historical Dracula, Vlad the Impaler, and the fictional vampire, Count Dracula (Light 2012: 3). Dracula tourism is mainly connected with Romania, although there is some Dracula tourism also in Great Britain. The latter is associated solely with the fictional Dracula and the locations visited are in Whitby and London, whereas Dracula tourism in Romania is associated with both the fictional and the historical Dracula. Tourists may visit the Dracula locations on their own, but most Dracula tourists usually go on Dracula tours organised by different travel agencies. These tours differ in their length and choice of visited locations associated with either of the 
Draculas. Although the emphasis on these tours is obviously on history and traditions about Vlad the Impaler as well as the fiction connected with Bram Stoker's book and vampires in general, much more gets related on the tours. The reactions to Dracula tourism in Romania have always been mixed. Some people are against it, some are in favour and some are indifferent towards it. Those who oppose Dracula tourism see it as something that could be harmful to Romanian culture and history. (Light 2012: 135-136). One could say that there is and has always been a conflict between Romanian heritage and Western stereotypes and fiction within Dracula tourism in Romania.

Dracula tourism can be hard to categorise as a particular type of tourism. It can be seen as cultural tourism, literary tourism, movie-induced tourism or dark tourism. In addition, it also includes elements of heritage tourism. Cultural tourism can be explained as incorporating all movements of people to specific cultural attractions, such as heritage sites, artistic and cultural manifestations, arts and drama outside their normal venues, or all the movement of people to cultural attractions away from their normal places of residence, with the intention of gathering new information and experiences to satisfy their cultural needs (Richards 2010: 15). Heritage tourism is a special form of cultural tourism. One way to make a distinction (if needed) between cultural tourism and heritage tourism is their relationship to the past. It can be argued that in heritage tourism the focus is, or at least has been, more on the past, whereas in cultural tourism the focus is on the present (Poria \& Butler \& Airey 2003: 240). Heritage is also a much narrower concept than culture, because heritage is selective. Heritage is always just a selected part of history and culture, one that is deemed especially important and desirable to be kept. Heritage is also a cultural process and a present-centred cultural practice, and even an instrument of cultural power (Harvey 2007: 37; Timothy \& Boyd 2003: 2-5). There is also a clear distinction between heritage and history. Unlike history, heritage does not necessarily need to be scientifically proved to be real. According to David Lowenthal, while history seeks to convince by truth and succumbs to falsehood, heritage exaggerates, omits, invents, forgets and thrives on ignorance and error (Lowenthal 2007: 111). Dracula tourism has many things in common with cultural and heritage tourism, because as well as visiting the sites connected with Vlad or the fictional Dracula, tourists also visit many culturally and historically important sites.

While Dracula tourism has elements of both cultural tourism and heritage tourism, it can also be defined as literary or movie-induced tourism. Literary tourism is the kind of tourism in which tourists visit the locations that either have connections to certain writers, or that form settings for novels (Herbert 2001: 314). Movie-induced tourism, which nowadays cannot really be separated 
from literary tourism, is the kind of tourism in which tourists visit destinations or attractions that they have seen on television, on video or on the cinema screen (Busby \& Klug 2001: 317). In some cases, tourists also visit literary or movie-induced landscapes to engage with broader meanings, values and myths than just the location itself. This is quite evident in Dracula tourism, in which tourists visiting Transylvania can engage with the ideas of otherness and superstitions beyond Stoker's original Dracula (Light 2012: 16-18). The term media tourism has also been suggested to combine both literary and movieinduced tourism, and it is, in my opinion, a very good one, because the two are often hard to separate from each other, and this term can also incorporate the Internet, which also affects and influences tourism (Reijnders 2011: 3-4). Popular culture tourism is also an appropriate term used to portray this kind of tourism (Larson \& Lundberg \& Lexhagen 2013).

The premise for Dracula tourism is obviously Bram Stoker's novel published in 1897 , but, in my opinion, it is the subsequent movies that have had an even stronger influence on Dracula tourism. Although Dracula tourism could be defined as literary, movie-induced or media tourism, the elements of horror and death that are attached to Dracula tourism link it also to dark tourism. Dark tourism is seen as travel to places associated with death, disaster and destruction. It has been called thanatourism, morbid tourism, Black Spot tourism, grief tourism and even "milking the macabre" (Sharpley 2009: 9-10). Dark tourism can be divided into places that have a direct link to terrible happenings and are therefore darker in nature, and those that also present real or fictional death and macabre events, but in more family-friendly settings or in a socially more acceptable environment in which to gaze upon simulated death and associated suffering, and which are therefore lighter in nature (Stone 2006: 152-157). A form of dark tourism, in which the tourist seeks a scary opportunity at a destination that may have a sinister history or may be promoted to have one, has been called fright tourism, or alternatively ghost tourism, spook tourism or haunting tourism (Bristow \& Newman 2005: 215; Light 2012: 62). The way I see it, Dracula tourism can definitely also be defined as dark tourism. It actually combines elements of fictional fright tourism with real atrocities of history that are part of dark tourism in general. It is clear that Dracula tourism is hard to define definitely. It has elements of literary tourism, movie-induced tourism, media tourism, dark tourism, cultural tourism and heritage tourism. The definition of Dracula tourism seems to depend on the reasons that the tourist has for taking the tour, whether for the landscapes of literature or movies, for stimulated fear and danger, or out of interest in historical and cultural sites. Sometimes the division is not so straightforward and all of the above can be seen as motivations for the trip. 


\section{THE TWO DRACULAS}

As I mentioned earlier, there are actually two Draculas in Dracula tourism. Undoubtedly, the more famous is the fictitious vampire, Count Dracula, who first appeared in Bram Stoker's seminal work Dracula, first published in 1897. Count Dracula is a vampire from Transylvania, who in the original novel moves to Great Britain and terrorises people before he is hunted down and forced back to Transylvania, and eventually killed. The novel was a moderate success during Bram Stoker's lifetime, but it got widespread recognition only about ten years after Stoker's death, first via successful stage adaptations and later through films. The first real Dracula movie was Dracula made by Universal Studios in 1931 (Miller 2003: 15). Since the 1931 film, the character of the vampire Count Dracula has appeared in countless movies, TV-series, games, plays and books. According to David J. Skal, Count Dracula has been depicted in films more times than almost any other fictional being, and is actually the second most portrayed fictional character on screen, with only the character of Sherlock Holmes appearing in more films (Skal 2004: 5, 299). Although there are countless films that feature Dracula, the one that has mostly influenced Dracula tourism, at least in terms of imagery, is Bram Stoker's Dracula from 1992. The film was directed by Francis Ford Coppola and starred Gary Oldman as both Vlad the Impaler and Count Dracula (which indeed were one and the same character in the movie).

The other Dracula is the so-called historical Dracula, Vlad the Impaler, who was a Wallachian prince, a voivode who reigned on three different occasions in the mid-fifteenth century, in 1448, 1456-1462 and 1476 (Treptow 2000: 33). Vlad the Impaler was also known as Vlad III or Vlad Dracula. In Romania, Vlad is mostly known by his cognomen Ţepeş, which means 'impaler'. This name was attached to him in the fifteenth to sixteenth century (Stoicescu 1978: 184). This cognomen came from the old and painful execution method of impaling, which was by no means an invention of Vlad. There are several stories and documents in which Vlad is said to have used this method quite often, and it is therefore ascribed to him (Rezachevici 2006; Stoicescu 1978: 187). The other name, Dracula, derives from the name of Vlad's father Vlad Dracul (Vlad II), who was the voivode of Wallachia in 1436-1442 and then again in 14431447 (Treptow 2000: 33). In 1431, Vlad Dracul was invested with the Order of the Dragon, an organisation founded by the German Emperor Sigismund of Luxemburg and dedicated to defending western Catholicism against heretics and infidels. Vlad Dracul most probably wore the golden chain of the order with a dragon insignia all the time, which is why he was associated with the dragon. The cognomen Dracul or Draculea comes from this association, and Vlad the 
Impaler simply inherited the name (Andreescu 1999: 183). In fact, the name was also ascribed to Vlad Dracul and to his other sons and not just to Vlad the Impaler (Stoicescu 1978: 181-183). The reputation of Vlad the Impaler has been twofold ever since the fifteenth century. The fact that he was and still is known so widely is because of the story tradition with folk narratives about him that started during Vlad's lifetime, already in the fifteenth century. The most famous and widespread stories can be divided into German, Russian (or Slavic) and Romanian stories.

The German and Russian stories were circulated in print and in manuscript form around Europe and Russia from the fifteenth century onwards. The German stories were printed around (modern) Germany between 1488 and 1559-1568 (Harmening 1983: 81-87). The Russian stories are in manuscript form and they were copied many times in different parts of Russia in the sixteenth, seventeenth and eighteenth centuries, but not printed until the nineteenth century. Of these about twenty manuscripts are extant to this day (Florescu \& McNally 1989: 208; McNally 1982: 127; Striedter 1961: 421). The Romanian stories were used as the basis for many of the German and Russian versions and have, for the most part, remained in oral form, although some Romanian stories were collected and written down as early as the sixteenth or seventeenth century (Andreescu 1999: 207-208; Stăvăruş 1978: 51). Many of these stories were collected from the village of Arefu in 1969 by Georgeta Ene (1976). Although there are many similarities between them, these three story collections differ from each other in tone and especially in the way that they portray Vlad the Impaler. The German stories portray Vlad as a bloodthirsty madman, the Russian stories as a very cruel but just ruler, and the Romanian stories as a just ruler. In Romania, Vlad the Impaler has almost always been seen as a good ruler, harsh but just. Vlad has been seen as a national hero who defended his country and people against foreign and domestic threats. Outside Romania, his image has been a lot darker, that of a bloodthirsty tyrant responsible for the lives of tens of thousands of people. At least since the 1970s, Vlad the Impaler has also been linked with the fictitious vampire, Count Dracula, especially in Western popular fiction and the media (Light 2012: 46-47).

Vlad the Impaler is often presented as a basis or inspiration for Stoker's vampire. Most of the links that have been created between the two Draculas are more or less artificial. However, sometimes this linkage is so strong or is seen as so obvious that the names Count Dracula and Vlad the Impaler have even become synonymous. This somewhat erroneous connection has been made in the media, in guidebooks and in academic books and articles, and has been used in literature, movies, TV-shows and comics. One of the major contributors to this connection was the book, In Search of Dracula: A True History of Dracula and 
Vampires, authored by Raymond T. McNally and Radu Florescu and originally published in 1972. While it was not the first scholarly work to suggest that Vlad was the inspiration for Stoker's novel, it did bring both the connection and Vlad the Impaler to public attention. McNally and Florescu's book was a bestseller and has continued to influence many writers and scholars even to this day (Light 2012: 47; Miller 2000: 181). Even though In Search of Dracula has been hugely influential, it has its shortcomings especially in dealing with the supposed connections between Vlad the Impaler and Stoker's Dracula. In these parts of the book, the writers rely quite heavily on assumptions and suppositions and also make some mistakes or misleading statements (Miller 2000: 181). Elizabeth Miller has quite convincingly challenged many of the facts in the connection, both in McNally and Florescu's book and in other publications, especially in Dracula: Sense and Nonsense (Light 2012: 48; Miller 2000). Vlad the Impaler is not the same figure or character as Count Dracula, nor is Vlad the inspiration or model for Count Dracula. The two share the name 'Dracula' and a few obscure historical references that Bram Stoker found in a book about the history of Wallachia and Moldavia (Miller 2000: 180-189). Despite this, the idea of these two characters as being one and the same can still be found in the media, literature, and even in some academic articles and books. The idea is also well used in Dracula tourism.

\section{HISTORY OF ROMANIAN DRACULA TOURISM}

After the early years of state socialism, during which Romania was all but closed to foreign tourists, the country began to turn attention to the development and promotion of international tourism in the late 1950s. During the 1960s, Romania became one of the most accessible socialist countries for Western tourists, and in the 1970s tourism was promoted towards the West primarily for political and propaganda motives. The majority of the international tourists were to be found where their holidays were concentrated, along the Black Sea coast, but by the mid-1970s other forms of tourism around the country were developed as well. This was also the time when some Dracula enthusiasts from the West, who were eager to see for themselves the locations found in Bram Stoker's book and in the Dracula films, started to visit Romania. For many tourists Transylvania was a particularly interesting destination to visit. Transylvania had and still has a special meaning in Western popular culture as a mysterious land of vampires and other supernatural things. The connection is so strong that the fact that Transylvania is a real place comes as a surprise to many Westerners (Hupchick 1995: 49; Light 2012: 28, 57-63). This type of tourism was a minority 
interest in Romania since most of the foreign tourists were from other socialist countries and knew very little about the vampire Dracula. To most Romanians the only link to the name Dracula was from Romanian history and from Vlad Dracul. Also, most of the Western tourists visited beach or mountain resorts and Dracula was not an important part of their holidays. According to Duncan Light, Dracula tourists were not a homogeneous group, and Dracula tourism was (and still is) a diverse phenomenon embracing a broad range of interests and motives. Some of them could be identified as literary tourists, some as film tourists, some were looking for the supernatural roots of the Dracula myth, and some were interested in the historical Dracula, Vlad the Impaler. The later interest in Vlad has also been partly the result of the success of the movie Bram Stoker's Dracula from 1992.

Dracula tourism was tolerated by the Romanian government, but it was not encouraged. Romania wanted to use international tourism to celebrate the agenda and achievements of state socialism and to raise the country's international profile, and, as such, Dracula tourism based around a belief in the supernatural and vampires was fundamentally discordant with Romania's identity as a socialist state (Light 2012: 69). Nevertheless, the Romanian government realised that the Dracula connection would offer considerable economic benefits, so the government sought ways to manage the phenomenon and even developed its own version of Dracula tours, which concentrated solely on the historical Dracula, Vlad the Impaler. Romanian tourism, and especially the numbers of tourists from the West, grew throughout the 1970s. In consequence, more and more people who were interested in Dracula came to Romania. Many tourists who participated in the Dracula tours offered by the state were disappointed because the experience did not match their expectations. They were expecting an experience based on Bram Stoker's novel and the vampire fiction in general, but, instead, they got a historical overview of a largely unknown Romanian ruler from the fifteenth century. And although the tour organised by the state was aimed at a clear differentiation between the fictitious Count Dracula and Vlad the Impaler, it actually ended up furthering the confusion between the two (ibid.: 71-72).

During the 1980s, conditions in Romania deteriorated as a result of President Nicolae Ceauşescu's policies. Ceauşescu wanted to reduce Romania's dependence upon Western Europe and introduced severe austerity measures in order to pay off the country's foreign debt. This involved, for example, reducing of domestic consumption and investment and rationing of energy supplies. The result was a decline in living standards for Romanians with rationing of food, electricity and fuel, which also affected tourism. Although there were still some tourists visiting Romania because of Dracula, the attitudes towards Dracula tourism 
and the whole Dracula phenomenon hardened. The label "Dracula" was also applied to Ceauşescu in the Western press in a negative way, which reduced the government's eagerness to associate itself with the Western Dracula even further. The Romanian government also began to view Western tourists with suspicion, and foreigners became the subject of careful surveillance by the regime. The number of tourists visiting Romania declined significantly, and by the end of the 1980s it was no longer a very attractive destination for Western tourists (Ionescu 1986: 25; Light \& Dumbrăveanu 1999: 901; Light 2012: 82).

After the 1989 revolution, tourism in Romania started to grow, but at first this growth was erratic. By the mid-1990s, tourism was actually in a state of stagnation and decline (Light \& Dumbrăveanu 1999: 903-905). The decline reached its bottom in 2002, when Romania received fewer foreign visitors than in 1989. However, after 2003, the number of foreign tourists started to grow again, and in 2008 visitor arrivals reached 8.9 million, which was the highest figure ever recorded, although the economic crisis caused a small decline in arrivals soon after that (Light 2012: 120). After 1989, Dracula tourism also started to grow. In the early 1990s, Dracula tourists continued to visit Romania, but their numbers were far lower than before the 1980s. After 1993, their number started to increase, partly because of the success of the film Bram Stoker's Dracula. Many of the tourist agencies that offered Dracula tours were foreign, and the ones in Romania were still offering tours themed around the life of Vlad the Impaler. The Transylvanian Society of Dracula, originally a Romanian nonpolitical, non-profit, cultural-historical non-government organisation founded in 1991, started to organise Dracula tours in the early 1990s. Initially they worked in partnership with a private travel agency in 1992, and from 1994 onwards through their own travel agency, the Company of Mysterious Journeys. The company added new elements to its tours, particularly evening performances in the village of Aref, which included traditional dancing and telling of local folktales about Vlad the Impaler, as well as witch-trial performances and various tests of knighthood; it also added locations, stories and features about the fictitious Dracula, as well as other traits derived from the vampire myth in general (ibid.: 124-125). Several other Romanian travel agencies copied many of these activities for their own tour itineraries. Today Dracula tourism in Romania is operated by a number of different travel companies, both foreign and domestic.

\section{THE HISTORY OF VLAD THE IMPALER IN TOUR NARRATIONS}

Although tourists can visit Dracula sites on their own, most of the Dracula tourism is based on tours that visit different sites connected with either the fictional Count Dracula or Vlad the Impaler. The majority of these tours start 
in the capital city, Bucharest. After Bucharest the tours visit sites that may or may not include the monastery island of Snagov, where Vlad is thought to have been buried, the princely ruins in Târgovişte, Sighişoara, the alleged birthplace of Vlad the Impaler, the medieval city of Braşov, which Vlad famously attacked, and the castle of Bran, which is marketed as Dracula's castle, the ruins of the Poenari citadel and the village of Aref, where people still tell stories about Vlad the Impaler, the monastery in Curtea de Argeş, the Transylvanian cities of Sibiu, Cluj-Napoca and Mediass, which all have some connections to Vlad the Impaler, and Hunyad castle in Hunedoara, where Vlad was held prisoner. All of these sites are more or less connected with Vlad and not with the vampire Count Dracula. Actually there are only two sites clearly connected with the fictional Dracula, which are visited on Dracula tours, namely the city of Bistriţa with its famous hotel, Coroana de Aur, and the Hotel Castel Dracula near the Borgo (Tihuţa) Pass. These two hotels were built in the 1970s and 1980s clearly to cater for Dracula enthusiasts who were looking to see more Dracula-themed sites in Romania (Light 2012: 76-78). Some sites that are visited on Dracula tours seem to have no connections to either Vlad the Impaler or to the Dracula of fiction (Hovi 2011: 82). These sites include Peleş Castle, the fortified church in Biertan, the city of Turda, the Danube delta, and the painted churches of Moldavia. I find these sites especially interesting because of lack of connection between them and either of the two Draculas.

At the sites that are connected with Vlad the Impaler, the tour guides usually focus on the history and tradition of the voivode. This can be traced to both history books about Vlad and to the German, Russian and Romanian fifteenth-century legend tradition. In Bucharest, where most Dracula tours start, the travel agencies usually organise a sightseeing tour around the city centre. Although Vlad has strong historical connections with Bucharest, the emphasis in the tour narrations on these sightseeing tours is actually much more on the history of Bucharest and Romania in general and especially the revolution of 1989 than it is on Vlad. All that is told about Vlad in connection with Bucharest is the fact that the city was first mentioned in a document signed by him (Treptow 2000: 182), and that Vlad either built or reinforced the fortress there. Other than these two points, Bucharest in Dracula tourism seems to function more as an orientation towards Romanian history, culture, and the whole Dracula tour than an actual Dracula site as such. The reasons for the emphasis on the 1989 revolution might lie in the fact that this is still fresh in the memory, there are many places in Bucharest with direct links to the events of the revolution, and it is seen as a very important moment in Romanian history. The fact that there are no locations connected with Vlad other than the palace ruins might also be of consequence. 
Close to Bucharest is the island monastery of Snagov, which is visited on most tours. Snagov is the supposed burial place of Vlad the Impaler, and most of the tour guide narrations concentrate on the stories connected with Snagov and Vlad's alleged tomb, and around the history of Vlad's death. Before 2011 there was no bridge to the island and the only way to get there was by boat, which added to the mysterious feel of the visit. Since the bridge was built, it is much easier for tourists to visit the island. Tourists visit the monastery church and are shown Vlad's presumed burial place, and then walk around the church and the small island before heading back. In Târgovişte, in the ruins of the Poenari fortress and in the village of Aref, the focus is clearly on the legends of Vlad the Impaler as well as the history of fifteenth-century Wallachia. Many of the story variants from German, Russian or Romanian traditions are connected with either Târgovişte or Poenari. For example, the famous Romanian story about the construction of the fortress by noblemen from Târgovişte connects these two sites together and is also told on several tours. In Târgovişte the tourists visit the ruins of the princely court and especially the sunset tower, which has a small exhibition about Vlad the Impaler. The tour guides tell stories about Vlad and Târgovişte as the tourists walk around the ruins or visit the exhibition (which is only in Romanian). The stories told in Târgovişte are known in all three traditions - German, Russian and Romanian. In Poenari the tourists climb the stairs (about 1480 steps) up to the ruins of the citadel. During the climb and while visiting the ruins, the tour guides usually tell stories about Vlad that are connected to Poenari, like the one about the construction of the citadel. Another famous Romanian story is about the suicide of Vlad's wife and his escape from the Poenari fortress (Ene 1976: 583). This story is also told in Poenari, even to the extent that the actual place where Vlad's wife must have killed herself is shown to tourists. Most of them deal with the punishments inflicted by Vlad the Impaler or about Vlad's strict sense of justice.

Yes, because when they arrived in the citadel of Poenari, they were surrounded by the Turkish army. And his wife was a very pretty woman, this is the story, and I suppose she was a very pretty woman; she preferred to die instead of remaining a prisoner of the Turks. And she jumped straight down from the wall of the citadel. And this was a cruel moment in the life of Ţepeş. ${ }^{6}$

The Transylvanian cities of Braşov, Sighişoara, Cluj-Napoca, Mediaş and Sibiu all have various connections with the history of Vlad the Impaler. Visits to these cities usually involve a sightseeing walk around the city centre, during which the tour guide talks about the site. Surprisingly, the actual emphasis in tour guide narrations in these cities is not on Vlad but on the medieval histories of 
these cities in general; while the cities share some history related to Vlad, it seems that it is not enough to build the whole tour around it. This is notable, for example, in the cases of Cluj-Napoca and Mediaş, which both have only a weak link with Vlad. ${ }^{7}$ Sibiu's main connections with Vlad the Impaler are that his son Mihnea the Bad was buried there and that he attacked the outskirts of the city in the fifteenth century; the tour narrations here are also about the culture and history of the town in general. Sighişoara is the alleged birthplace of Vlad the Impaler, where his father lived before he became the voivode of Wallachia, but other than that the city does not have much of a connection with Vlad. Sighişoara is one of the Romania's seven UNESCO World Heritage Sites and is often branded as the "best preserved fifteenth-century walled town of Europe" or "one of Europe's most beautiful and still inhabited fortified cities". ${ }^{8}$ In Sighişoara, the tour narrations often focus on the history of the town as well as the cultural meaning of the town as a UNESCO World Heritage Site, and also emphasise the town's medieval history. Besides, Sighişoara is the place where most of the Halloween parties are organised if the tour takes place during that time.

Of all the Transylvanian cities Braşov may have the most pertinent and famous history relating to Vlad the Impaler. It was an important and rich medieval city close to the border with Wallachia. The wealthy Saxon merchants of Braşov exercised a great deal of influence in Wallachian politics, which caused tension between the Wallachian rulers and the Saxon merchants and councillors of Braşov. This was also the case during Vlad's time and, after several incidents with the merchants and councillors of Braşov, he attacked the city and punished them. This attack is depicted in one of the most famous German stories about Vlad, in which he is said to have had his breakfast in the midst of several impaled victims from the city (Treptow 2000: 100-101, 217). Despite this history and the obvious connections, the tour narratives again emphasise the city as a medieval Transylvanian town and its later history, and not the connections with Vlad the Impaler. Vlad is mentioned as having attacked Braşov and impaled many people from the city on Tâmpa Mountain, which looms over the city, but other than that there really does not seem to be anything else to tell about Vlad in the tour narrations in Braşov. Braşov and Sighişoara, although important places in the history of Vlad the Impaler, seem to be marketed more as medieval Transylvanian cities that are important to Romanian culture and history, and not as actual Dracula sites. The Middle Ages are emphasised because at some of the locations the connections with Vlad the Impaler may be too thin and, on the other hand, because there are a number of stereotypical impressions of the Middle Ages, which also fall in line with the stereotypical images of Vlad. Most of these impressions come from 
popular culture and are expected to be known to tourists. Most of the tourism in the abovementioned places focuses on history and could be categorised mainly as cultural or heritage tourism rather than literary tourism, movie-induced tourism or dark tourism, with may be minor exceptions in the cases of Sighişoara (especially during Halloween), Târgovişte and partly also Braşov, where parts of the tours might also be considered as dark tourism. One of the highlights on the Dracula tours during Halloween is a Halloween party, which is usually, although not always, organised in Sighişoara. During the parties the tour guides as well as the tourists dress up in different Halloween costumes and partake in various activities suited to the theme, such as, for example, the ritual killing of the living dead, Dracula's wedding, or a tournament. Here the tourists partake in the lighter side of dark tourism. In Târgovişte and Braşov the tour narrations partly focus on the alleged atrocities committed by Vlad the Impaler, and can therefore be seen as dark tourism.

\section{FICTION IN TOUR NARRATIONS}

Fiction plays a major role in Dracula tourism for obvious reasons, and it is also used on the tours. Tour guides make use of fiction in their narrations in two ways. Sometimes it is stated or brought up explicitly, and sometimes only hinted at. On the two Dracula tours by the Company of Mysterious Journeys that I participated in, the distinction was made clearly in the tourist guide narrations by stating explicitly that the group was leaving behind history and reality and crossing into the domain of the fictitious Count Dracula, as, for example, on the itinerary from the company's Classic Dracula Tour:

Proceed to the buffer-zone separating Count Dracula's domain (the county of Bistrita-Nasaud) from the rest of Transylvania. Prince Vlad dims out into history; Count Dracula emerges from nightmares, terror and fright. ${ }^{9}$

Fiction is mostly used on the route from Sighişoara or from Braşov to Bistriţa and to the Borgo Pass, or, in other words, from the sites that are associated with Vlad the Impaler to the sites that are associated with Bram Stoker's book. So the tour guides tend to make a clear distinction between what they perceive as real Romanian history and fiction and Western popular culture. In the Castel Dracula Hotel in the Borgo Pass, the focus on fiction is also quite obvious. Here the tour narrations revolve around the idea of the hotel as the home of the fictional vampire, Count Dracula.

Some of them prefer to sleep there instead of sleeping in the castle. Some of them are afraid of what can happen in the castle after midnight. And for this, nobody can condemn them. ${ }^{10}$ 
Even when Count Dracula is not explicitly mentioned, the tour narrations usually play with the idea of the myth of Transylvania as a place. According to Duncan Light, a place myth is a culturally constructed idea about the nature of a certain place, regardless of its character in reality. Place myths are formed from sometimes exaggerated or incomplete images of the place, often based on stereotypes or even prejudices, and are maintained by different forms of popular culture (Light 2012: 20). Bram Stoker created or at least consolidated a powerful and enduring place myth of Transylvania as a marginal, backward, sinister and supernatural location (ibid.: 30 ). The place myth of Transylvania is used in tour narrations quite clearly to constantly emphasise the fact. The tourists are told that the many crosses that can be found alongside the roads are there to protect them and that one should not wander beyond them. Similar things are told in the Castel Dracula Hotel, where the tourists are warned not to wander around the hotel. ${ }^{11}$ It is clear that the tour guides assume that the tourists share this idea of the place myth of Transylvania as being something dangerous and superstitious. On the tours, Bistriţa and the Borgo Pass are also often referred to as Dracula County, or the Count's domain.

The Coroana de Aur (Golden Crown) hotel in Bistriţa was built in the 1970s and it shares its name with the hotel in which Jonathan Harker slept overnight and ate in Bistriţa on his way to Dracula's castle in Bram Stoker's book (ibid.: 76). In addition to the name, the hotel has one special dining room called 'Salon Jonathan Harker', which is decorated accordingly. The hotel is usually visited only briefly on the way to the Castel Dracula Hotel, but some tours stop there for a longer visit, and tourists can eat the 'same meal' as Jonathan Harker did in the novel, called the Jonathan Harker menu. Other than the name, the dining room and the special menu, the hotel has little to do with Dracula tourism in terms of decorations or activities. The Castel Dracula Hotel was built in the 1980s near the top of the Bârgau (Borgo) Pass, more or less where the castle of Count Dracula was situated in Stoker's novel (ibid.: 101-104). Although it has a tower and an inner courtyard, the hotel itself is not a real castle as such, but a hotel made to look like one. It is actually an interesting mix between the socialist architecture of the 1980s and a medieval castle.

The hotel is decorated with a Dracula theme up to a certain point, but to many tourists it is actually a bit of a disappointment. Many of the tourists that I interviewed were disappointed with the hotel and felt that it did not live up to their expectations and that it could also have had much more potential as a tourist site. One tourist mentioned that the tourist industry would need to re-work the interior and "goth" or "Disneyfy" the castle up, meaning to make it more acceptable or marketable to its core target group. There is a cellar in the hotel where tourists can go and visit Dracula's coffin. Usually, while the 
tourists are down in the cellar, the lights suddenly go out and "Dracula" escapes from the coffin, frightening the tourists. After this the tourists usually go outside where they are greeted by Dracula (a hotel worker in a Dracula costume), and led to a fireplace where they can partake in activities and listen to ghost stories around the fire. There is also a small (real) cemetery near the hotel, which is sometimes visited. Occasionally, Halloween parties are also organised in the hotel. After the tour leaves the Castel Dracula Hotel and Bistriţa, the emphasis of the tour narrations turns back to the historical and cultural aspects of Romania. The tours that are held during Halloween also tend, however, to emphasise the fictional side at other locations than just Bistriţa and the Castel Dracula Hotel. Tourism in Bistriţa and in the Borgo Pass is a mix of dark tourism and media tourism. Tourists are clearly told that this is the setting for Bram Stoker's novel and that they are actually following Jonathan Harker's footsteps. So tourists can, in a way, re-enact or perform parts of the novel or the movies in 'actual' settings (Light 2009: 193-194; Reijnders 2011: 13). The dark tourism part comes with the scare elements and spooking of the tourists. In addition to Bistriţa and the Borgo Pass, the fictional element on the tours can sometimes also be found when visiting Sighişoara and Castle Bran. Because Vlad the Impaler is thought to have been born in Sighişoara, the idea that it is the birthplace of Dracula is sometimes played upon. This is especially the case during the time of the Halloween parties that are organised there. Castle Bran is also a place where the lines between history and fiction are sometimes blurred. It was dubbed "Dracula's castle" for American tourists in the 1970s and the name has stuck ever since, even though the castle has nothing to do with Count Dracula and has only a minor historical link to Vlad the Impaler. Yet Bran is sometimes mentioned as being Dracula's castle, or as being the inspiration for Dracula's castle in Stoker's book, or as the location where many Dracula movies have been filmed.

\section{ADDITIONAL HISTORY USED IN TOUR NARRATIONS}

Despite their name, Dracula tours do not focus solely on the two Draculas. As mentioned earlier, there are several sites that are visited on the tours, which have nothing to do with either Vlad the Impaler or Count Dracula. These sites include the castle of Peleş, the fortified church in Biertan, the city of Turda, the Danube delta and the painted churches of Moldavia. ${ }^{12}$ The reasons for sites like these to be included in the Dracula tours vary, but one of the main justifications is that the organisers want to show them to foreign tourists. This is the case especially with Peleş Castle, which is visited on tours organised by both the Company of Mysterious Journeys and Transylvania Live. 
Yes, because like I've said, we want to present also what is good in our history, and Peleş Castle is one of the most beautiful 19th-century castles in Europe. And because it's very beautiful, we try to present it also to our tourists, to show also the other face of Romania, the romantic face of Romania. ${ }^{13}$

Well, yeah. Well, I would say yes, yes, because you're still in Romania, and from my point of view you should, you should learn a few things about Romania, too. And plus we are passing next to the place, we know that it's a unique... it's like, like you said like Peleş Castle, it's a unique place in Romania and there won't be too many like that around Europe, so from my point of view it's a very good thing. ${ }^{14}$

Peleş Castle, which is a castle built for the Romanian royal family at the turn of the twentieth century, is shown to tourists because it is considered as something important for Romanian culture (Hovi 2011: 83). The late nineteenth and early twentieth centuries are also seen as a kind of a golden age in Romania and Peleş Castle is a reminder of that era. As the tour guide from Transylvania Live told me, it is important for him that tourists learn something about Romania while they are there, even if they are in Romania just because of Dracula. The addition of these sites and tour narrations may also function as a way to connect Romania, through its history, to Western Europe, and emphasise the fact that before the communist times Romania had stronger connections with the West. After all, the Romanian royal family came from Germany and therefore shares a link with other European royal families. The fortified church in Biertan and the painted monasteries in Moldavia are UNESCO World Heritage Sites, so it is easy to see why the travel agencies also want to show them on Dracula tours. Important sites for Romanian culture, both past and present, like Peleş, Biertan, and the monasteries in Moldavia, are willingly brought into conjunction with western and foreign vampire and horror thematics. According to Pekka Hakamies, it is not unusual that in some cases people have been clinging to old traditions as a form of silent protest against a dominant ideology and government, which have been regarded unfamiliar or foreign. At the same time, this kind of protest has worked as a unifying force that has strengthened local identity (Hakamies 1998: 11). Similarly, the addition and marketing of these kinds of sites can be seen as a local cultural protest against a foreign and unfamiliar image of Romania. And, at the same time, this can be seen as a way to strengthen local identity and culture against a foreign (and in this case a cultural) threat (Hovi 2011: 83).

Bucharest is interesting as a Dracula site, because, as I stated earlier, it does not actually function as such. It seems to operate more as an orientation 
towards Romanian history, culture and the whole Dracula tour than an actual Dracula site as such. In fact, the emphasis of the tour narrations in Bucharest seems to be on the events of the 1989 revolution. This is not entirely surprising since the effects of the revolution can still be clearly seen in the street scenes in Bucharest. In addition to the history of the city and the events of the revolution, the tour narrations also relate the development of Romania since the revolution up to the present day. The tour narrations associated with the revolution focus on various buildings and events that took place at different sites in the city, such as the Palace of Parliament, the Memorial of Rebirth in Revolution Square, which commemorates the struggles and victims of the revolution of 1989, and University Square. One reason for the emphasis on the 1989 revolution might also be the fact that in the aftermath, Romania fell more in line and became connected with Western Europe and the Western world. Maybe the tour guides want to emphasise this change as well.

This part of the tours and visits to the abovementioned locations is more cultural and heritage tourism than media or dark tourism. The city of Turda is visited on some Dracula tours, and it also has no connections to either of the Draculas. It is, however, a mix of cultural or heritage tourism and dark tourism. The main location to visit in Turda is the old salt mines, which is an important historical as well as a heritage site. However, the place where tourists stay is a hotel called Hunter Prince Castle and Dracula Hotel, which is often marketed as "a medieval fantasy with beds". The hotel has hunting-themed, as well as Dracula-themed, decorations, with a special dining room called Dracula's Castle, which is filled with Dracula- and horror-themed decorations. In there, tourists can eat a special themed menu and have their photos taken beside a life-sized figure of Vlad the Impaler, or by an "executioner's block".

Besides Bucharest and the sites that are not connected to either of the Draculas, there are also tour narrations that are told between sites. Because the distances between some of the Dracula sites are long, plenty of time is spent sitting on a bus. These moments are usually spent listening to the tour guides, sleeping, watching movies or talking to other tourists. Depending on the tour guides, most of the tour narrations between the sites are stories about various Dracula sites, about Romanian history and culture in general, personal views and experiences in Romania on the part of the guides, and modern Romania in general, so the tour narrations may consist of more or less anything about Romanian history, culture and modern everyday life. Whether or not they are interested in hearing about other matters than those related to Dracula, Vlad, vampires and Transylvania depends on the tourists: some are not interested at all, whereas others are very interested in the overall history and culture of Romania. ${ }^{15}$ Because the usual tour itineraries go from Wallachia to Transylva- 
nia and back, tourists also get to see geographically varied parts of Romania; according to one tour guide that I interviewed, this is seen as important for the guides that tourists gain a better image and understanding of the country.

\section{CONCLUSION}

What kind of history is used and what eras of history are related in the tour narrations in Dracula tourism in Romania? The answer can roughly be divided according to four historical eras. The first is the time of Vlad the Impaler and the Middle Ages in general. These tour narrations are used at the sites connected to Vlad and at those that may have a looser connection to him but anyway have medieval history attached to them. The reasons for focusing on this era of history are quite self-evident and self-explanatory. The second era is the turn of the twentieth century; this era is used in the tour narration in Peleş Castle and also in Bucharest. This tour narration functions as a reminder of Romania's shared past with Western Europe. The reason for this focus seems to be a desire to recount this period as one of importance for the history of Romania, and to establish a connection between Romania and Western Europe through history. The third era is socialism and especially its demise with the 1989 revolution. The tour narrations about this era are usually told in Bucharest as well as on the road, in between the different tour sites. In Bucharest the narrations are linked with different buildings and events that took place around the city. The reasons for including this era are probably that the socialist era is still relatively fresh in the memory, and the fact that such a different system intrigues tourists, especially Western tourists, to whom the socialist system is unfamiliar. The fourth era is the present day. These tour narrations are more unofficial by nature and therefore also more difficult to conceptualise. They are usually told in between the different sites and their content depends on the tour guides. Usually they are about the personal experiences and opinions of the guides. This era is included because it gives information about the current state and culture of Romania, which is both interesting to the tourists and felt as important for the guides to tell. The history that is left out on the Dracula tours seems to cover the period in Romanian history before the Middle Ages, as well as most of the time between the sixteenth and the late nineteenth centuries. Also, the early twentieth century, with the far-right movement in Romania, as well as the first decades of the Communist rule, seems to be missing in the tour narrations. Romanian history before the Middle Ages is probably not seen as that interesting in this context, and the same applies to some other time periods. So the eras that are seen as important enough to be told to the tourists are Vlad's 
era, the era in which Romania first grew closer to the West, the socialist era, which is seen as something strange and negative, and the present day, which is seen as more modern, free and western, especially after the era of socialism.

It is by no means a revelation that tourists are told about the history and culture of their destination in general, not even when they are participating in a themed tour, such as a Dracula tour. It is, however, interesting to see how and why this is done. In the case of Dracula tourism in Romania, it actually answers the second question raised in my article: How can the seemingly superficial and fictitious Dracula tourism be used as a gateway into Romanian history and culture? Dracula tourism, although indeed seemingly superficial, can be used as such a gateway by adding sites that have nothing to do with Vlad the Impaler or the fictitious Count Dracula, by recounting the history and culture of Romania in general and not just focusing on the Middle Ages, and by trying to separate the fictional side of Dracula tourism from the history side. Dracula tourism may be used, and actually is used, as a marketing tool for Romania. So we might even say that through Dracula tourism one can find the "real" Romania, which of course is much more than just the "land of Dracula". The reason for adding places like the castle of Peleş, Biertan, or the salt mines in Turda, is to give the tourists an image of Romania that is as extensive and positive as possible. By telling Romanian history and culture in general and by showing different historical, cultural and geographical sides of the country, travel agencies want to offer their version of Romania alongside the fictional Dracula's country.

Although the Dracula theme is constantly present on the tours, most of the locations visited do not actually have any connections with the fictional Dracula. This is interesting, considering that most of the tourists are interested mainly in the figure from popular culture, and hence this can cause friction by not coincide with the tourists' expectations. One strategy for the travel agencies to negotiate this friction between history and fiction is in the way that the tours are organised. For the most part, the tours visit places that are of historical value and are mainly connected with Vlad the Impaler but not with the vampire, Count Dracula. The only locations directly associated with the fictitious Dracula are Bistriţa and the Borgo Pass, which are quite far from the rest of the locations visited on the tours. This gives the tour operators an opportunity to concentrate all, or at least most, of the fictional side of Dracula tourism within this part of the tour. This approach is also quite clearly stated in many tour itineraries in terms of crossing the border to Dracula's county or to the domains of the count. And when the tours proceed onwards, the tour itineraries mention that it is time to leave fiction and return to history. So, one way that the agencies manage the balance between history and fiction 
is to clearly focus the fictional part of the tour on these two locations. This is certainly not always so black and white and not every tourist agency operates like this. Especially many foreign tourist agencies seem to deliberately confuse the two characters throughout the entire tour. It seems, however, that most of the Romanian tourist agencies do separate the two characters, particularly by focusing the fictional part of the tour only on Bistriţa and the Borgo Pass, with the small exceptions of Bran and Sighişoara.

Dracula tourism has been opposed because it has been seen as something foreign and even as a threat to Romanian culture and history. The argument has been that Dracula tourism could give rise to a wrong image of Romania. The results of my fieldwork with the two Romanian travel agencies that offer Dracula tourism, the Company of Mysterious Journeys and Transylvania Live, show that this concern is at least partly unfounded. Although both of these agencies use fiction and play with the idea of the place myth of Transylvania, they tend to offer plentiful information about the history and culture of Romania. So, to my mind, Dracula tourism is not necessarily a threat to Romanian culture and history, but can actually help to promote both. Romanian Dracula tourism is an example of how a local agent can negotiate with a form of tourism and culture that is foreign, without having to compromise or lose one's own culture.

\section{NOTES}

1 Romanian National Tourist Office, http://www.romaniatourism.com/history.html, last accessed on January 15, 2014.

2 Romanian National Tourist Office, Special Interest, http://www.romaniatourism.com/ special-interest.html, last accessed on January 15, 2014.

3 Although many historical and mythical figures, such as Robin Hood, William Wallace (Braveheart), King Arthur or many characters of the Wild West have been absorbed into Western popular culture, this all has been done more or less within the same Anglo-American culture and on the culture's own terms. And often the historical and popular culture characters have been combined with the interest and understanding of the culture from which they originate. In the case of Dracula tourism, the character of Vlad the Impaler has been "forcefully" attached to the western vampire Dracula without any input from Romanian culture.

${ }^{4}$ Like, for example, the Company of Mysterious Journeys, http://www.mysteriousjourneys. com/dracula_tours/castle_dracula/travel/, and Transylvania Live, http://www.draculatour.com/halloween-dracula-tour-in-transylvania.html, both last accessed on January 15,2014 .

5 These tours are The Classic Dracula Tour (April 2012) and The Classic Dracula \& Halloween 2010 in Transylvania (October 2010) by the Company of Mysterious Journeys, and Vampire in Transylvania - Halloween Departure Tour (October 2011) by 
the company Transylvania Live. I have decided to leave the tour guides anonymous in this article. All of the interviews are in the possession of the author, both in transcribed versions and as audio files.

${ }^{6}$ An interview conducted by the author with a tour guide from the Company of Mysterious Journeys in 2010 (English slightly corrected, as also in other interviews).

7 The links with Vlad in these cities are quite vague. Cluj-Napoca is the birthplace of Mathias Corvinus, who impacted Vlad's life in many ways, and Vlad was held prisoner in Mediaş for a short while, but that is about as far as the connection goes.

8 Company of Mysterious Journeys, http://www.mysteriousjourneys.com/halloween2012-transilvania/ (page not available any more) and Transylvania Live, http://www. dracula-tour.com/europe-sightseeing-tours-romania/dracula-tour-transylvania-travel. html, last accessed on January 15, 2014.

9 The Classic Dracula Tour, http://www.mysteriousjourneys.com/dracula_tours/classic_ dracula_level_1/, last accessed on January 15, 2014.

${ }^{10}$ An interview conducted by the author with a tour guide from the Company of Mysterious Journeys in 2010.

11 These are based on the author's fieldwork notes.

12 The company of Mysterious Journeys organises Dracula tours that also visit Biertan, the Danube delta, and the painted monasteries of Moldavia. Transylvania Live organises tours that visit Turda, and both travel agencies visit the castle of Peleş on their tours.

${ }^{13}$ An interview conducted by the author with a tour guide from the Company of Mysterious Journeys in 2010.

${ }^{14}$ An interview conducted by the author with a tour guide from the Transylvania Live in 2011.

${ }^{15}$ Personal communication with a tour guide from the Company of Mysterious Journeys in 2010 .

\section{REFERENCES}

Andreescu, Stefan 1999. Vlad the Impaler: Dracula. Translated by Ioana Voia. Bucharest: The Romanian Cultural Foundation Publishing House.

Bristow, Robert S. \& Newman, Mirela 2005. Myth vs. Fact: An Exploration of Fright Tourism. In: Kelly Bricker \& Sarah J. Millington (eds. \& comps.) Proceedings of the 2004 Northeastern Recreation Research Symposium. General Technical Report NE-326. Newtown Square, PA: United States Department of Agriculture, Forest Service, Northeastern Research Station, pp. 215-221. Available at http://www. fs.fed.us/ne/newtown_square/publications/technical_reports/pdfs/2005/ne_gtr326. pdf, last accessed on January 15, 2014. 
Busby, Graham \& Klug, Julia 2001. Movie-Induced Tourism: The Challenge of Measurement and Other Issues. Journal of Vacation Marketing, Vol. 7, No. 4, pp. 316-332. http://dx.doi.org/10.1177\%2F135676670100700403.

Ene, Georgeta 1976. Romanian Folklore about Vlad Ţepeş. Revue des Études Sud-Est Européennes, Vol. 14, No. 4, pp. 581-590.

Florescu, Radu R. \& McNally, Raymond T. 1989. Dracula: Prince of Many Faces: His Life and His Times. Boston \& New York \& London: Little, Brown and Company.

Hakamies, Pekka 1998. Perinne, etninen identiteetti ja yhteiskunnan murros. [Tradition, Ethnic Identity and Change in Society.] In: Pekka Hakamies (ed.) Ison karhun jälkeläiset. [Progeny of the Great Bear.] Helsinki: SKS, pp. 7-23.

Harmening, Dieter 1983. Der Anfang von Dracula. Zur Geschichte von Geschichten. [The Beginning of Dracula: On the History of Stories.] Würzburg: Königshausen + Neumann.

Harvey, David C. 2007. Heritage Pasts and Heritage Presents: Temporality, Meaning and the Scope of Heritage Studies. In: Laurajane Smith (ed.) Cultural Heritage: Critical Concepts in Media and Cultural Studies, Vol. I. London \& New York: Routledge, pp. 25-44.

Herbert, David 2001. Literary Places, Tourism and the Heritage Experience. Annals of Tourism Research, Vol. 28, No. 2, pp. 312-333. http://dx.doi.org/10.1016\%2 FS0160-7383\%2800\%2900048-7.

Hovi, Tuomas 2011. Dracula Tourism, Folklore and Cultural Heritage. Traditiones, Vol. 40, No. 3. Acta Instituti ethnographiae et instituti ethnomusicologiae Slovenorum, pp. 75-86. http://dx.doi.org/10.3986\%2FTraditio2011400305.

Hupchick, Dennis P. 1995. Conflict and Chaos in Eastern Europe. Basingstoke: Palgrave Macmillan.

Ionescu, Dan 1986. Who's Afraid of Dracula? Index on Censorship, Vol. 15, No. 8, pp. 24 25. http://dx.doi.org/10.1080\%2F03064228608534143.

Larson, Mia \& Lundberg, Christine \& Lexhagen, Maria 2013. Thirsting for Vampire Tourism: Developing Pop Culture Destinations. Journal of Destination Marketing \& Management, Vol. 2, No. 2, pp. 74-84. http://dx.doi.org/10.1016\%2Fj. jdmm.2013.03.004.

Light, Duncan 2009. Halloween in Transylvania. In: Malcolm Foley and Hugh O’Donnell (eds.) Treat or Trick? Halloween in a Globalising World. Newcastle upon Tyne: Cambridge Scholars Publishing, pp. 186-200. Available at http://www.c-s-p.org/ flyers/978-1-4438-0153-9-sample.pdf, last accessed on January 15, 2014.

Light, Duncan 2012. The Dracula Dilemma: Tourism, Identity and the State in Romania. Farnham: Ashgate.

Light, Duncan \& Dumbrăveanu, Daniela 1999. Romanian Tourism in the Post-Communist Period. Annals of Tourism Research, Vol. 26, No. 4, pp. 898-927. http://dx.doi. org/10.1016\%2FS0160-7383\%2899\%2900033-X.

Lowenthal, David 2007. Fabricating Heritage. In: Laurajane Smith (ed.) Cultural Heritage: Critical Concepts in Media and Cultural Studies, Vol. III. London \& New York: Routledge, pp. 109-124.

McNally, Raymond 1982. Origins of the Slavic Narratives about the Historical Dracula. In: Stephen Fischer-Galati \& Radu R. Florescu \& George R. Ursul (eds.) Romania 
Between East and West. Historical Essays in Memory of Constantin C. Giurescu. Boulder: East European Monographs, pp. 127-145.

McNally, Raymond T. \& Florescu, Radu 1994 [1972]. In Search of Dracula: The History of Dracula and Vampires. Boston \& New York: Houghton Mifflin Company. Miller, Elizabeth 2000. Dracula: Sense \& Nonsense. Essex: Desert Island Books Limited. Miller, Elizabeth 2003. A Dracula Handbook. Bucharest: Editura GEROT.

Poria, Yaniv \& Butler, Richard \& Airey, David 2003. The Core of Heritage Tourism. Annals of Tourism Research, Vol. 30, No. 1, pp. 238-254. http://dx.doi.org/10.1 016\%2FS0160-7383\%2802\%2900064-6.

Reijnders, Stijn 2011. Stalking the Count: Dracula, Fandom and Tourism. Annals of Tourism Research, Vol. 38, No. 1, pp. 231-248. http://dx.doi.org/10.1016\%2Fj. annals.2010.08.006.

Rezachevici, Constantin 2006. Vlad Tepes and His Use of Punishments. Journal of Dracula Studies, No. 8 [online]. http://www.blooferland.com/drc/images/4/42/08RezVT.rtf, last accessed on January 16, 2014.

Richards, Greg 2010. The Traditional Quantitative Approach. Surveying Cultural Tourists: Lessons from the ATLAS Cultural Tourism Research Project. In: Greg Richards and Wil Munsters (eds.) Cultural Tourism Research Methods. Wallingford: CABI Publishing, pp. 13-33. http://dx.doi.org/10.1079\%2F9781845935184.0013.

Sharpley, Richard 2009. Shedding Light on Dark Tourism: An Introduction. In: Richard Sharpley \& Philip R. Stone (eds.) The Darker Side of Travel. The Theory and Practise of Dark Tourism. Bristol: Channel View Publications, pp. 3-22.

Skal, David J. 2004. Hollywood Gothic. New York: Faber and Faber.

Stăvăruş, Ion 1978. Povestiri medievale despre Vlad Ţepeş-Draculea. [Medieval Stories about Vlad Tepes Dracula.] Bucharest: Editura Univers.

Stoicescu, Nicolae 1978. Vlad Ţepeş, Prince of Walachia. Translated by Cristina Krikorian. Bucharest: Editura Academiei Republicii Socialiste Romania.

Stone, Philip R. 2006. A Dark Tourism Spectrum: Towards a Typology of Death and Macabre Related Tourist Sites, Attractions and Exhibitions. Tourism, Vol. 54, No. 2, pp. 145-160.

Striedter, Jurij 1961. Die Erzählung vom walachischen Vojevoden Drakula in der russischen und deutschen Überlieferung. [The Story of the Wallachian Voivode Dracula in the Russian and German Tradition.] Zeitschrift für Slavische Philologie,Vol. 29, pp. 398-427.

Timothy, Dallen J. \& Boyd, Stephen W. 2003. Heritage Tourism. Essex: Pearson Education Limited.

Treptow, Kurt W. 2000. Vlad III Dracula: The Life and Times of the Historical Dracula. Iaşi: The Center for Romanian Studies. 